This item was submitted to Loughborough's Research Repository by the author.

Items in Figshare are protected by copyright, with all rights reserved, unless otherwise indicated.

\title{
Functional components of public expenditure, fiscal consolidations and the economic activity
}

PLEASE CITE THE PUBLISHED VERSION

https://doi.org/10.1111/ecpo.12104

\section{PUBLISHER}

(c) Wiley

VERSION

AM (Accepted Manuscript)

\section{PUBLISHER STATEMENT}

This is the peer reviewed version of the following article: CASTRO, V., 2018. Functional components of public expenditure, fiscal consolidations and the economic activity. Economics and Politics, 30(1), pp. 124-150, which has been published in final form at https://doi.org/10.1111/ecpo.12104. This article may be used for noncommercial purposes in accordance with Wiley Terms and Conditions for Use of Self-Archived Versions.

\section{LICENCE}

CC BY-NC-ND 4.0

\section{REPOSITORY RECORD}

Castro, Vitor. 2019. "Functional Components of Public Expenditure, Fiscal Consolidations and the Economic Activity”. figshare. https://hdl.handle.net/2134/27485. 


\title{
Functional components of public expenditure, fiscal consolidations and economic activity ${ }^{*}$
}

\author{
Vítor Castro ${ }^{\mathrm{a}, \mathrm{b}, *}$ \\ ${ }^{a}$ School of Business and Economics, Loughborough University, UK \\ ${ }^{\mathrm{b}}$ Economic Policies Research Unit (NIPE), Portugal
}

\begin{abstract}
This paper analyses how the functional components of public expenditure and spending-driven consolidations affect the economic growth, unemployment and income inequality. A dynamic panel data LSDVC estimator is employed over a sample of 15 European Union countries during the period 1990-2012. The empirical results show that real GDP growth decreases when fiscal austerity measures are implemented, especially if they are spending-driven. Cuts in public expenditure undermine economic growth, namely if they slash spending on public order, recreation and education. Spending cuts on education, in particular, affect the investment in human capital, harming not only growth but also economic, social and human development. The unemployment rate also proved to be significantly boosted when austerity measures restrict spending on education, while income inequality rises when social protection expenditures are cut.
\end{abstract}

Keywords: Functional components of public expenditure; Fiscal consolidations; Economic growth; Unemployment; Income inequality; European Union.

JEL classification: D63; E24; E62, H50; O47.

\footnotetext{
* The author wishes to thank the financial support provided by the Portuguese Foundation for Science and Technology under the research grant SFRH/BSAB/113588/2015 (partially funded by COMPETE, QREN and FEDER). This paper was written while the author was visiting the Faculty of Economics, University of Cambridge, UK. He is grateful for the facilities provided by this University to develop his research.

- Address for correspondence: School of Business and Economics, Loughborough University, Loughborough, Leicestershire LE11 3TU, UK. Phone: +44 (0)1509222706; E-mail: v.m.q.castro@lboro.ac.uk
} 


\section{Introduction}

The funds transferred by fiscal authorities to rescue the banking sector and the discretionary measures adopted by several European Union (EU) countries, in particular, to boost the economic activity in the aftermath of the recent Great Recession led to considerable fiscal deficits and pushed government debts to historically high levels. Consequently, this forced EU countries to abandon those expansionary fiscal policies and to design austerity programmes. The Greek crisis boosted this process, as countries wanted to convince the markets that they were in a better and solid position. Hence, several consolidation and austerity packages started to be implemented to correct those unbalances. At the same time, this process revived the interest of the academics in studying their economic impact and implications. In particular, the fiscal austerity measures implemented recently by several EU countries have intensified the discussion on their impact over the economic activity and the well-being of their citizens.

While the EU institutions emphasize the importance of fiscal consolidations as a requirement for a sustainable growth in the long-run, the US argue that they hurt short-term growth and longer adjustment periods should be allowed. Assessing the trade-off between consolidation of public finances and economic growth is fundamental for the formulation of effective policies. Several studies have looked at this relationship between fiscal consolidations and economic growth (see, among others, Alesina and Ardagna, 1998, 2010; Perotti, 2011; Anderson et al., 2014; Cugnasca and Rother, 2015). The role of the kind of a consolidation (spending or tax-driven) and its composition are also taken into account in the literature (Alesina and Perotti, 1995, 1997; McDermott and Wescott, 1996; Alesina and Ardagna, 1998, 2010; Gupta et al. 2005; Silva et al., 2013). Tax cuts are found to be more expansionary than spending increases. Regarding the composition, they assess the impact of expenditure components on economic growth considering the economic decomposition of public expenditures. 
On the effects over unemployment, there are fewer studies. For example, Turrini (2013) shows that this impact is temporary and relevant only for public expenditures. A few recent papers are moving the focus of the analysis to the distributional effects of fiscal austerity measures (see, for example, Ball et al., 2013; Agnello and Sousa, 2014).

Nevertheless, as far as we are concerned, no study analyses how the functional components of public spending affect economic growth, unemployment or income inequality. Thus, this study represents an important step forward relatively to the previous literature, as it allows us to identify and understand which and how the functional components of public expenditure affect the economic activity. Additionally, this analysis allows us to draw some suggestions in terms of the design of fiscal consolidations by fiscal authorities regarding their main functions: providing public services, defence, public order and safety, housing amenities, health services, recreation and culture, education, social protection, etc. Knowing the impact of those components on the economy allows fiscal authorities to take action to mitigate the negative economic and social effects of spending-driven fiscal consolidations and to avoid the deterioration of the well-being of the most vulnerable citizens.

An LSDVC estimator is used in the empirical analysis over a panel of EU countries and the results show that real GDP growth decreases when spending-driven fiscal austerity measures are implemented. Cuts in public expenditure undermine economic growth, especially if they slash spending on public order, recreation and education. Spending cuts on education, in particular, affect the investment in human capital, harming not only growth but also economic, social and human development. The unemployment rate is also boosted when austerity measures restrict spending on education, while income inequality rises when social protection expenditures are cut. 
This article is organized as follows. Section 2 presents a brief review of the relevant literature. Section 3 describes the data and presents the econometric model. The main results are presented and discussed in section 4 and section 5 concludes.

\section{Literature review}

The EU countries have faced important economic and social challenges in terms of weak economic growth, persistent unemployment and a perceived increase in income inequality. At the same time high budget deficits and public debts have forced several countries to implement austerity measures. Whether those measures are undermining even more the economic activity or not has revived the debate among politicians and economists.

In the literature, there are several papers looking at the impact of fiscal consolidations on economic growth. Giavazzi and Pagano (1990) challenge the idea of a positive fiscal multiplier by arguing that fiscal consolidation adjustments can have an expansionary impact on the economic activity. Later, Perotti (1999) shows that consolidations can indeed be expansionary when the public debt is high or when it is growing very quickly. In the same line, Alesina and Ardagna (1998, 2010), Miller and Russek (2003) show that growth performance is improved after periods of drastic and decisive spending cuts. Furthermore, Alesina and Perotti (1995, 1997), McDermott and Wescott (1996) and Alesina and Ardagna (1998) state that the composition of public accounts matters to understand the private sector response to fiscal policy and the consequent impact on growth. They show that fiscal adjustments that rely on cuts in transfers and wages tend to last longer and can be expansionary, while those that rely on tax increases and cuts in public investment are contractionary.

Considering a sample of low-income countries, Gupta et al. (2005) also shows that strong budgetary positions are generally associated with higher economic growth in both the short and 
long terms. They also confirm that the composition of public outlays also matters in those countries. In particular, countries where spending is concentrated on wages tend to have lower growth, while those that allocate higher shares to capital and nonwage goods and services enjoy faster output expansion. More recently, Silva et al. (2013) also show that transfers are the driving force of the expenditure dynamics, with wages exhibiting a negative impact on output, while positive effects arise from shocks in public investment.

Using a structural VAR approach, Blanchard and Perotti (2002) find that positive government spending shocks increase output, consumption and decrease investment, while positive tax shocks have a negative effect on output, consumption and investment. However, in the cases of fiscal stimulus, Alesina and Ardagna (2010) show that tax cuts are more expansionary than spending increases. Forni et al. (2010) presents a more radical finding as they conclude that the best fiscal consolidation strategy is to permanently reduce both expenditures and tax rates. They argue that with this consolidation strategy the transition is generally not costly, as the GDP and investment would grow. Developing a two country DSGE model, Erceg and Linde (2013) show that tax-based consolidations have smaller adverse effects on output than expenditure-based consolidations in the near-term, though is more costly in the longer-run.

Nevertheless, the works on endogenous growth have suggested that fiscal policy can either promote or undermine economic growth as investment in physical and human capital can affect steady-state growth rates (Barro, 1991; Barro and Sala-i-Martin, 1995). Thus, while Easterly et al. (1994) support the belief that healthy budgetary balances are good for growth over the long-run, others argue that the effect of fiscal consolidation on growth in the short-run can have negative consequences (see Cimadomo et al., 2010; Perotti, 2011; Silva et al., 2013; Anderson et al., 2014; Cugnasca and Rother, 2015; among others). In particular, Perotti (2011) argues that spending cuts cause significant short-run output losses. 
Studies on the impact of fiscal consolidation on unemployment are scarce. For example, with respect to public employment, Heylen et al. (2013) find that public wage bill cuts do not contribute to lower public debt ratios when public sector efficiency is high. In a study for a panel of EU countries, Turrini (2013) shows that the impact of fiscal consolidations on unemployment is temporary and significant mainly for expenditures.

The distributional effects of fiscal austerity are also under the scope of some studies (Mulas-Granados, 2005; Ball et al., 2013; Agnello and Sousa, 2014; Furceri et al., 2015; Agnello et al., 2016; among others). Income inequality is observed to rise during fiscal consolidations especially if they are spending-driven. In particular, Mulas-Granados (2005) finds that successful fiscal consolidations are associated with higher income inequality. Ball et al. (2013) and Agnello and Sousa (2014) corroborate this finding. Moreover, Agnello and Sousa (2014) shows that consolidations driven by spending cuts are more detrimental for income distribution than those driven by tax hikes. Agnello et al. (2016) provide a regional analysis for 13 European countries and argue that fiscal consolidations that rely on reductions in government spending can exacerbate regional disparities and may ultimately counteract the European policy efforts to promote territorial cohesion. In contrast, Ball et al. (2013) find that both expenditure and taxed-based fiscal consolidations at the national level have typically raised inequality for a panel of OECD countries, even if the distributional effects of spending-based adjustments tends to be larger relative to tax-based adjustments. Furceri et al. (2015) also show that fiscal consolidations increase income inequality, but they also show that they lower wage income shares in the short and medium-term.

In this paper, we take a step forward relatively to the existing studies in order to identify and understand which and how the functional components of public expenditure affect the economic activity in a panel of 15 EU countries. Moreover, we also provide a comparative 
analysis between a particular group of countries - recently affected by unfavourable economic and financial conditions, increasing public deficits and debts and that have implemented harsh austerity packages - known in the literature as PIIGS (Portugal, Ireland, Italy, Greece and Spain) and the other ten EU countries. This analysis allows us to draw some proposals in terms of the design of fiscal consolidations by fiscal authorities and contribute to the debate on their impact over economic growth, unemployment and income inequality.

\section{Data and model specification}

To analyse the impact of the functional components of government expenditures (and fiscal consolidations) on the economic activity, we collected annual data for the 15 countries that were members of the European Union in the end of the 1990s. The main reason to consider only those EU countries is that the disaggregated fiscal data for other EU countries is of poor quality. Even for the selected countries, the available data provided by the Eurostat database for the functional components of public expenditure covers only the period 1990-2012. ${ }^{1}$ Hence, we are forced to restrict our analysis to that time period.

Three specifications are considered to estimate the impact of the fiscal variables on the economic activity. The first accounts for their impact on real GDP growth:

$$
\text { RealGDP }_{i t}=\alpha+\gamma \operatorname{RealGDP}_{i t-1}+\boldsymbol{\beta E c o n}_{i t}+\boldsymbol{\theta F i s c a l}_{i t}+\delta \text { Trend }_{i t}+v_{i}+e_{i t}
$$

\footnotetext{
${ }^{1}$ The countries (data availability) considered in this study are: Austria (1995-2012), Belgium (1990-2012), Denmark (1990-2012), Finland (1990-2012), France (1995-2012), Germany (1991-2012), Greece (1990-2012), Ireland (1990-2012), Italy (1990-2012), Luxembourg (1990-2012), Netherlands (1995-2012), Portugal (1990-2012), Spain (1995-2012), Sweden (1995-2012), United Kingdom (1990-2012).
} 
where $i=1, \ldots, 15, t=1990, \ldots, 2012$. RealGDP represents the real growth rate of GDP; the coefficient on its lag $(\gamma)$ accounts for its persistence. The vector $\boldsymbol{\beta}$ captures the impact of the economic controllers, while $\boldsymbol{\theta}$ measures the impact of the fiscal variables. A time-trend is also included in the specification to account for the evolution of real GDP growth and any technological changes over time. Regarding the last components, $v_{i}$ is the individual effect of each country $i$, and $e_{i t}$ is the error term.

The set of economic variables includes proxies for the traditional determinants of output growth (see, for example, Bassanini and Scarpetta, 2001; Gupta et al., 2005): the growth rate of the labour force as percentage of total population (LabourForce); the growth rate of private investment as percentage of GDP (PrivInvestment); the average number of years of schooling (Schooling), to control for the human capital endowment in each country; the growth rate of trade openness, computed as imports plus exports as percentage of GDP (Openness); and the growth rate of the long-term interest rate on government bonds (Interest), to account for the monetary policy dynamics. ${ }^{2}$ The data for these variables, and for the dependent variable (RealGDP), were collected from the Eurostat database, except for the average years of schooling which comes from the World Development Indicators (WDI) of the United Nations.

The vector of the fiscal variables comprises two sub-sets of co-variates: the first accounts for the fiscal consolidations; and the second for the public expenditures and respective functional components. Fiscal consolidation episodes were identified using the work of Devries et al. (2011) for the period 1990-2009 and updated from Kataryniuk and Vallés (2015) for the years 2010-2012. Both authors use a narrative approach to identify those consolidations. For the missing data for Greece and Luxembourg, we are consistent with the narrative approach and

\footnotetext{
${ }^{2}$ Most of the variables used in this study are in growth rates to avoid the unit root problems. Stationarity tests are not reported here, but they are available upon request.
} 
combine the information provided by Kataryniuk and Vallés (2015), Dellepiane and Hardiman (2012) and OECD (2011) country notes on Restoring Public Finances to obtain the respective consolidation periods and kind. ${ }^{3}$ Hence, our fiscal consolidation variable (Consolidation) is a dummy variable that takes the value of one in the years in which a fiscal consolidation is being implemented (zero, otherwise). To account for the impact of the kind of fiscal consolidation on the economic activity we use two alternative dummy variables: SpendConsol and TaxConsol. Following Devries et al. (2011), SpendConsol takes the value of one if the consolidation is driven by a spending cut (zero, otherwise) and TaxConsol takes the value of one if the consolidation is driven by an increase in taxation (zero, otherwise). According to the literature, we expect that fiscal consolidations, especially spending-driven, might have a significant and strong impact on the economic activity. ${ }^{4}$

The total general government expenditures (TotalSpending) and each of the respective components are considered in the next sub-set. That analysis is based on a break-down of government expenditures as defined by the OECD in its Classification of the Functions of the Government (COFOG). ${ }^{5}$ It classifies government expenditure data from the System of National Accounts by the purpose for which the funds are used, also called functional decomposition. This classification splits public expenditures into ten functional components: (i) general public

\footnotetext{
${ }^{3}$ As argued by Devries et al. (2011), the standard statistical approach which focuses on variation in the cyclically adjusted primary budget balance (CAPB) may lead to biased results for two reasons. First, the CAPB may suffer from measurement error that is likely correlated with economic developments. Second, it omits periods during which fiscal consolidation programs are followed by adverse shocks, offsetting discretionary measures. For these reasons, we follow the narrative approach, which is based on the examination of accounts and records of what countries were intending to do at the time of publication of different institutional reports, to uncover policy actions that are motivated by deficit reduction. See notes at the bottom of Table A.1 in Annex for the years of fiscal consolidations.

${ }^{4}$ See, among other references, Alesina and Ardagna (2010), Gupta et al. (2005), Forni et al. (2010), Perotti (2011), Silva et al. (2013), Turrini (2013), Anderson at al. (2014), Agnello and Sousa (2014), Cugnasca and Rother (2015).

${ }^{5}$ See OECD (2015), Government at a Glance.
} 
services (PublicServices); (ii) defence (Defence); (iii) public order and safety (PublicOrder); (iv) economic affairs (EconAffairs); (v) environmental protection (Environment); (vi) housing and community amenities (Housing); (vii) health (Health); (viii) recreation, culture and religion (Recreation); (ix) education (Education); (x) social protection (SocialProtect). We expect that some of these components affect real GDP growth in a significant way.

In fact, our expectation for the consolidation and fiscal variables relies on the Keynesian theory. Keynes showed that aggregate demand and growth may remain low after a shock if the government does not intervene to boost the economy. Hence, expansionary fiscal policy, by increasing public spending on investment and consumption, raises demand for more products and services and stimulates employment (or reduces unemployment to its natural level). This means that government expenditure can boost the economy and help to reduce unemployment. Therefore, we also conjecture that spending components will behave in the same way, with some being more influential than others. One of the aims of this study is precisely to identify which ones are more effective in stimulating economic growth, employment and equality. At the same time, the Keynesian view also supports our expectation that fiscal consolidations may undermine growth, boost unemployment and contribute for an increase in income inequality.

The second specification estimated in this study analyses how the labour market, in particular, the unemployment rate, reacts to changes in the functional components of public spending and fiscal consolidations. In this case, we estimate the following equation:

$$
\text { Unemp }_{i t}=\alpha+\gamma \text { Unemp }_{i t-1}+\boldsymbol{\beta E c o n}_{i t}+\boldsymbol{\theta F i s c a l}_{i t}+\delta \text { Trend }_{i t}+v_{i}+e_{i t}
$$

where $i=1, \ldots, 15, t=1990, \ldots, 2012$. Unemp represents the growth rate of the unemployment rate; the coefficient on its lag $(\gamma)$ accounts for its persistence. Once again, the vector $\boldsymbol{\beta}$ captures 
the impact of the economic controllers, while $\boldsymbol{\theta}$ measures the impact of the fiscal variables. The other components and the set of fiscal variables are the same as in equation (1). However, in this case, the economic controllers include: the output gap (OutputGap), computed as the difference between the potential and the actual GDP using the Hodrick-Prescott filter, to control for the business cycle; PrivInvestment; Schooling; Openness; and the growth rate of real wages (Wages), to account for demand-supply pressures in the labour market. ${ }^{6}$

The last issue to consider in this study is whether (and how) the fiscal variables (consolidations and spending components) affect the distribution of income or, more precisely, the income inequality. To estimate this relation, we consider the following specification:

$$
\text { Gini }_{i t}=\alpha+\gamma \text { Gini }_{i t-1}+\boldsymbol{\beta} \text { Econ }_{i t}+\boldsymbol{\theta F i s c a l}_{i t}+\delta \text { Trend }_{i t}+v_{i}+e_{i t}
$$

where $i=1, \ldots, 15, t=1990, \ldots, 2012$. The dependent variable, Gini, represents the growth rate of the Gini index; the coefficient on its lag $(\gamma)$ accounts for its persistence. ${ }^{7}$ In this case, we use as proxies for its economic determinants: the growth rate of real GDP per capita (RealGDPpc); Schooling; Openness; and Wages. The other components remain identical to the ones considered in equation $(1) .^{8}$

\footnotetext{
${ }^{6}$ Once again, most of the variables are in growth rates to avoid the unit root problems. The data for the additional variables, and for the dependent variable (Unemp), were collected from the Eurostat database.

${ }^{7}$ The data for the Gini index comes from the Standardized World Income Inequality Database (SWIID). Nolan et al. (2009) state that this measurement of income inequality improves the comparability across different studies as it captures different points in the distribution and measures of income inequality levels and trends in a harmonised way. Solt (2009) also says that it provides a greater cross-country and temporal coverage. We focus on the definition that accounts for gross taxes; the results with the definition accounting for net taxes have proved to be weaker.

${ }^{8}$ Descriptive statistics for all the variables used in this study can be found in Table A.1 in Annex.
} 
Given the presence of individual effects $v_{i}$, all the three models can be estimated assuming those effects as fixed or random. However, the lagged value of each dependent variable would be correlated with the respective error term even if the latter is not serially correlated. This implies that OLS estimates (random or fixed effects) will be biased and inconsistent. Although the fixed effects estimator gains consistency as the number of time periods increases, in our analysis its number is not big enough ( $T=23)$ to rely on its estimates.

The estimators that take into account that bias can be grouped into instrumental variables estimators and bias-corrected estimators. According to the large sample properties of the generalized method of moments (GMM), the dynamic estimator proposed by Arellano and Bond (1991) is adequate when there is a clear dominance of cross sections over time periods in the sample. This is not the case in our panel, in which the cross sectional dimension is small $(N=15)$, and almost of the same dimension as the time periods $(T=23)$. This means that the dynamic panel data estimator developed by Arellano and Bond (1991) is not the most suitable procedure to solve the problem. More specifically, given our panel structure, it will also be biased if employed to this analysis. Hence, a bias-corrected estimator is more appropriated here.

Therefore, we apply Bruno's (2005a, b) bias-corrected least squares dummy variable estimator (LSDVC) for dynamic panel data models with small $N$ (and not large enough $T$ ). In the regressions, we employ the Blundell and Bond (1998) estimator as the initial estimator. In this case the instruments are collapsed as suggested by Roodman (2009), which makes sure that we avoid using invalid or too many instruments. Following Bloom et al. (2007), we undertake 50 repetitions of the procedure to bootstrap the estimated standard errors. ${ }^{9}$ The respective empirical results are presented and discussed in the next section.

\footnotetext{
${ }^{9}$ Bootstrapping the standard errors is a common practice when this estimator is applied because Monte Carlo simulations proved that the analytical variance estimator performs poorly for large coefficients of the lagged
} 


\section{Empirical results}

The findings of this study are carefully analysed and discussed in this section. We start by considering how real GDP growth reacts to the fiscal consolidations and spending components; then we move to a similar analysis for the unemployment rate; the last issue to be considered is the behaviour of income inequality. In each of these sub-sections we also account for the heterogeneity, providing a comparison between the PIIGS and the other ten EU countries.

\subsection{Economic growth analysis}

The results from the estimation of the impact of fiscal consolidations and the components of public expenditures on the economic growth are presented in Table 1. All variables are in growth rates (except Schooling, which is stationary in levels) to avoid the unit root problems. ${ }^{10}$ We start by looking at the impact of fiscal consolidations on GDP growth, before analysing the behaviour of public spending and the respective functional components.

\section{[Insert Table 1 around here]}

As expected and in line with some recent works by Cimadomo et al. (2010), Perotti (2011), Silva et al. (2013), Anderson et al. (2014) and Cugnasca and Rother, 2015, the results presented in column 1 show that fiscal consolidations (Consolidation) have a significant negative

dependent variable (see Bruno, 2005a, b). We should also stress that our results do not qualitatively change with more repetitions (100, 200 or even 500) or when either Arellano and Bond (1991) or Anderson and Hsiao (1982) estimators are used as initial estimators instead.

${ }^{10}$ Panel unit root tests are not reported here to save space, but they are available upon request. 
impact on GDP growth (RealGDP) in the short-term: during periods of fiscal consolidations the growth rate of real GDP is, on average, almost one percentage point lower than in the other periods. In regression 2, we account for the kind of consolidation instead. Our findings support the view that spending-driven consolidations (SpendConsol) have an immediate negative impact on growth, while tax-driven ones (TaxConsol) are less harmful (Perotti, 2011; Erceg and Linde, 2013).

As the implementation of spending-driven consolidations undermines economic growth, we proceed the analysis by looking at public spending (see column 3) and, most importantly, at the respective functional components (columns 4-8). ${ }^{11}$ The results reported in column 3 support the previous ones, as when total public spending (TotalSpending) is boosted, real GDP growth increases. This means that our evidence for public spending is in line with the Keynesian view. Hence, cuts in government spending (spending-driven austerity measures) have an immediate negative impact on economic growth. But, which components inside total public expenditure contribute more to that effect? The aim of the next analysis is to answer this question.

Column 4 reports the results with all the functional components of public expenditures in growth rates. They show that expenditures in public order, recreation and education are the components that contribute more for economic growth. Fiscal consolidations that promote cuts especially in those items will affect real GDP growth significantly. For the same group of EU countries, Castro (2016) shows that expenditures on defence, public order, health, education and social protection are significantly cut during fiscal consolidations, undermining citizens' safety, health assistance, investment in human capital and social protection. In this study, we show that

\footnotetext{
${ }^{11}$ For an analysis on the economic decomposition of public spending see Alesina and Perotti (1995, 1997), McDermott and Wescott (1996), Alesina and Ardagna (1998), Gupta et al. (2005) and Silva et al. (2013).
} 
from the expenditures that are usually cut during fiscal consolidations, the ones that end up having a more significant effect on growth are indeed public order and education.

We believe that spending on education plays an important role in this process, as decreases in the investment in human capital are known to have a significant negative impact on economic growth (see, for example, Bassanini and Scarpetta, 2001, and references therein). Regarding public order it is not so clear, but it is possible that spending on police services, fire-protection, law courts and safety in general can have a direct effect in terms of more employment and investment in this sector and an indirect effect in what concerns to social stability and safety that might benefit the overall economic environment. Additionally, the promotion of recreational and cultural activities (via recreational and sporting services, cultural services, broadcasting and publishing services, community services) seems to exert similar positive spillover effect over the economy.

These results and conclusions remain essentially unchanged when we consider the growth of the functional components of public expenditures per capita (column 5), fixed or random-effects estimators (columns 5 and 6 , respectively), ${ }^{12}$ or when we account for endogeneity on the fiscal variables (column 8). In the last regression presented in Table 1 we use an instrumental variables estimator where fixed effects are controlled for. It could be the case that economic growth itself influences fiscal variables. For example, when economic growth slows down, the components of government spending might decrease. Moreover, some degree of reverse causality could also be present in the relationship between growth and private investment. Hence, if economic growth is a determinant of any of the right-hand side variables in our model, estimation techniques that ignore this endogeneity will yield biased and inconsistent parameter

\footnotetext{
${ }^{12}$ The usual panel data tests (F, LM and Hausman tests) favour the fixed-effects estimator, even though in this dynamic panel data model they can be biased.
} 
estimates. The fiscal components are instrumented with their lags (as well as private investment), but reverse causality is not found to affect significantly the parameter estimates. Moreover, the endogeneity Durbin-Wu-Hausman test does not reject the null hypothesis of exogeneity.

Regarding the economic controllers, the results are in line with the expectations and the studies on economic growth: ${ }^{13}$ private investment and labour force promote economic growth; years of schooling contribute for a better economic performance, but the results are not so statistically significant; openness to trade also boosts economic growth; but the role of monetary policy has not proved to be relevant. Finally, besides the persistence in the dependent variable, we observe a decreasing trend in economic growth over the period 1990-2012 in the 15 EU countries considered in this analysis.

Next we provide a comparative analysis between the group of countries usually called in the literature as PIIGS (Portugal, Ireland, Italy, Greece and Spain) and the other ten EU countries considered in this study. The PIIGS are known for being more "relaxed" with their public accounts. However, recently they were affected by unfavourable economic and financial conditions which boosted their public deficits and debts. The unfavourable conditions that they have faced (recession and unemployment), the high levels of public deficits and debts that they present and the difficulties that they have felt in borrowing money to finance their economies were critical to account for this distinction. Due to those problems, they were forced to implement severe fiscal packages and some needed external financial assistant to overcome their financial and/or fiscal unbalances. This means that this we must pay a special attention to this group of countries in this analysis to check whether they present a different behaviour from the others or not.

\footnotetext{
${ }^{13}$ See, among others, Barro (1991), Barro and Sala-i-Martin (1995), Bassanini and Scarpetta (2001), Bassanini et al. (2001) and Gupta et al. (2005).
} 
The results from this separate analysis are shown in Table 2. We consider the same specification as in Table 1 and use the LSDVC estimator only. In the first set of four columns are reported the results for the PIIGS and in the second set the results for the other ten countries.

\section{[Insert Table 2 around here]}

The impact of fiscal consolidations on real GDP growth has proved to be negative and highly significant in both groups of countries, especially if they are spending-driven. Moreover, when total public spending is boosted, real GDP growth increases. These results support the previous ones for the whole sample and show that despite the specificities of these two groups of countries, they are similarly affected in terms of the economic growth when they implement fiscal authority packages.

When we look at the results for the components inside total public spending, despite the positive effect of spending on public order being confirmed for both groups of countries, things change a little in the other cases: while spending on recreation is relevant in the non-PIIGS, the positive effect of increasing spending in education is only found in the PIIGS. This means that cuts in education should be especially avoided in these countries as they have a significant negative impact on their growth path and, at the same time, might undermine their future human development.

In addition, we also observe that spending on environmental protection has a positive impact on real GDP growth in the PIIGS. Regarding the economic controllers, despite some particularities (labour force, interest rate,...), in general, the results are not very different from the ones obtained with the whole sample. 


\subsection{Unemployment analysis}

Another important issue to consider is how fiscal consolidations and expenditure components affect the labour market, more precisely, the evolution of unemployment in the economy. The analysis provided in Table 3 aims at shedding some light on that issue. Like economic growth has proved to be affected by fiscal consolidations and the changes it causes inside public expenditure, unemployment can also be affected by austerity measures that restrict important components of public spending.

\section{[Insert Table 3 around here]}

The results presented in the first three columns in Table 3 clearly show that the growth rate of unemployment is significantly affected by fiscal consolidations, especially those that are meant to cut spending. In sum, austerity measures that cut public spending end up boosting unemployment. This evidence is in line with the one obtained in the previous analysis for real GDP growth and corroborates the idea that fiscal austerity measures have an immediate negative impact on the economic activity.

The next set of results indicates which expenditure components influence the most the evolution of the unemployment rate. According to our findings, consolidations that aim at reducing spending on defence, public order and education are the ones that will contribute to a more significant boost in the unemployment rate. The same reasons indicated above for their impact on the real GDP growth can be considered here, as cuts in those areas will affect employment and investment in those sectors. Surprisingly, cuts (increases) in social protection are shown to be related to lower (higher) unemployment rates. In fact, social protection tends to increase when unemployment increases, so it is possible that we have here a reverse causality 
problem. In fact, when we control for endogeneity (in the same way as in the growth analysis), we observe that the coefficient on social protection is no longer significant (see column 8 in Table 3). The endogeneity test also points out to some marginal evidence of endogeneity. Anyway, solved this problem, the other results and conclusions remain valid.

Regarding the controllers, the results are also in line with our expectations and the economic literature. To account for the impact of the economic environment, we use the output gap: when it increases, the unemployment rate decreases significantly. Private investment and trade openness have a similar effect, while wage increases tend to put pressure on unemployment, maybe because labour is regarded as more expensive than the economic agents would expect. The number of years of schooling has not proved to be relevant in this analysis, but - similarly to what we have found for growth - the evolution of the unemployment rate has followed an increasing trend over the period in analysis for the $15 \mathrm{EU}$ countries here considered.

Similarly to what we have done in economic growth analysis, we also account next for heterogeneity issue. The separate results for the PIIGS and the other ten countries are reported in Table 4. The results show that the negative impact of fiscal consolidations on unemployment is significant only in the PIIGS. This might be the case because most of the fiscal austerity packages implemented in that group of countries (especially the ones implemented more recently) involve the reduction of labour force in the public sector and the restructuration of the labour market. Nevertheless, our results also show that cutting public spending end up boosting unemployment in both groups of countries.

\section{[Insert Table 4 around here]}


Regarding the components of public spending the results are mixed: (i) consolidations aimed at reducing spending on defence affect equally both groups of countries and are in line with the results for the whole sample; (ii) cuts in spending on economic affairs, environmental protection and public services are relevant only in the PIIGS; the unemployment rate is negatively affected by cuts in spending on public order and education only in the other group of countries.

Finally, in what concerns to the controllers, the main finding is that the economic environment, years of schooling and degree of openness seem to matter for the evolution of the unemployment rate in the other ten countries than in the PIIGS. Nevertheless, all the significant results are in both groups are line with the literature.

\subsection{Income inequality analysis}

In a final analysis, we look at the impact of fiscal consolidations and expenditure components behaviour on income inequality. Using a panel of 18 industrialized countries from 1970 to 2010, Agnello and Sousa (2014) show that income inequality rises during periods of fiscal consolidations, especially if they are driven by spending cuts. ${ }^{14} \mathrm{We}$ corroborate that evidence in our sample of 15 EU countries over the period 1990-2012, as can be seen in the results reported in Table 5 (see columns 1-3). However, we move a step forward in order to identify the spending components that play a major role in this process.

\section{[Insert Table 5 around here]}

\footnotetext{
${ }^{14}$ See also Ball et al. (2013), Furceri et al. (2015) and Agnello et al. (2016), this last for a regional analysis.
} 
Even thought the results reported in Table 5 are not as robust as in the previous analyses, one important message that arises from this analysis is that income inequality decreases significantly when government spending on social protection increases. Hence, fiscal consolidations that promote cuts in this component will contribute to a more unfair distribution of income and to an increase of inequalities in a society. This evidence remains valid even when we use per capita values for the expenditure components (in growth rates), fixed and random effects estimators and the IV estimator (with RealGDPpc and the fiscal components instrumented with their lags). In addition, we also observe that increases (decreases) in environment (housing) spending are negatively correlated to income inequality, but the results are not very robust to drawn clear conclusions.

Concerning the controllers, the growth rate of the Gini index has proved to decrease when the growth rate of real GDP per capita increases and when the growth rate of real wages decreases (and, to some extent, when the economy is less open to trade). While increases in wages are not promoting more equality, it is the growth in income per capita that does the most for income equality. Regarding the other controllers, no additional relevant results are found.

The results for the separate analysis between the PIIGS and the other ten countries are presented in Table 6. However, we have no evidence to corroborate that income inequality rises immediately during periods of fiscal consolidations (spending or tax-driven) in either group of countries. As already observed in the estimations for the whole sample, the evidence of short-term effects is weaker. In the spirit of the works of Ball et al. (2013) and Agnello and Sousa (2014), we conclude that the effects of fiscal consolidations over income inequality may take more time to be observed than the immediate effects on economic growth and unemployment.

\section{[Insert Table 6 around here]}


Nevertheless, when we look at the components of public spending we corroborate the finding that income inequality decreases significantly when spending on social protection increases. The results for the controllers remain essentially the same, with the growth rate of real GDP per capita playing the major role.

\section{Conclusions}

This paper analyses the impact of fiscal consolidations and the functional components of public expenditures on economic growth, unemployment and income inequality over a panel of 15 EU countries for the period 1990-2012. A separate analysis between five particular countries (called PIIGS) and the other ten EU countries is also considered.

The empirical analysis shows that real GDP growth decreases when fiscal austerity measures are implemented, especially if they are spending-driven. This result is also observed in both the PIIGS and the other ten EU countries. Hence, cuts in public spending undermine economic growth and the components that proved to drive this effect are public order, recreation and education. Fiscal consolidations that promote cuts in those items affect real GDP growth significantly, especially in the group of the five more vulnerable countries. In particular, spending cuts on education play an important role in this process, as decreases in the investment in human capital are detrimental not only for the growth path of a country but also for its economic, social and human development. Thus, fiscal consolidations must refrain from imposing strict and blind financial constraints or cuts on education spending; otherwise fiscal authorities can undermine not only a country's economic activity but also its future prospects of development.

The unemployment rate has also proved to be significantly affected by austerity measures that restrict important components of public spending. This trend has proved to be more relevant 
in the PIIGS. Those consolidations that aim at reducing spending on defence, public order and education are the ones that contribute to a more significant boost in the unemployment rate. The same reasons pointed out for education (in the real GDP growth analysis) can be considered here to convince fiscal authorities to refrain from cutting spending on education. Regarding the other sectors, cuts usually involve the reduction of public servants (jobs) and investments that end up exerting a negative effect in terms of the private sector investments, social stability and safety, with important spillover effects over the economy.

This analysis is not so successful in showing a short-term impact of fiscal consolidations on income inequality. However, we do find that income inequality decreases significantly when government spending on social protection increases. Hence, fiscal consolidations that promote cuts in this component foment a more unfair distribution of income and an increase of inequalities in a society.

The main message of this study can be summarized as follows: fiscal authorities must be careful when they design a fiscal austerity package in order to avoid cutting spending in those areas that can undermine the economy the most. Spending on education is one of the components that deserves a special attention in terms of the impact it has on the economic activity, while spending on social protection is detrimental to avoid an increase in income inequality. 


\section{References}

Agnello, L., Sousa, R., 2014. How Does Fiscal Consolidation Impact on Income Inequality? Review of Income and Wealth, 60 (4), 702-26.

Agnello, L., Fazio, G., Sousa, R., 2016. National fiscal consolidations and regional inequality in Europe. Cambridge Journal of Regions, Economy and Society, 9 (1), 59-80.

Alesina, A., Ardagna, S., 1998. Tales of fiscal contractions. Economic Policy, 27, 487-545.

Alesina, A., Ardagna, S., 2010. Large changes in fiscal policy: Taxes versus spending. In: Brown, J. R. (Ed.). Tax Policy and the Economy, Vol. 24, 35-68. National Bureau of Economic Research, NBER, The University of Chicago Press.

Alesina, A., Perotti, R., 1995. Fiscal expansions and adjustments in OECD countries. Economic Policy, 21, 205-248.

Alesina, A., Perotti, R., 1997. Fiscal adjustments in OECD countries: Composition and macroeconomic effects. IMF Staff Papers, 44(2), 210-248.

Anderson, D., Hunt, B., Snudden, S., 2014. Fiscal Consolidation in the Euro Area: How Much Pain Can Structural Reforms Ease? Journal of Policy Modeling, 36 (5), 785-99.

Anderson, T., Hsiao, C., 1982. Formulation and estimation of dynamic models using panel data. Journal of Econometrics, 18(1), 47-82.

Arellano, M., Bond, S., 1991. Some Tests of Specification for Panel Data: Monte Carlo Evidence and an Application to Employment Equations. Review of Economic Studies, 58, 277-297.

Ball, L., Furceri, D., Leigh, D., Loungani, P., 2013. The distributional effects of fiscal austerity. United Nations DESA Working Paper No. 129. 
Barro, R., 1991. Economic growth in a cross section of countries. Quarterly Journal of Economics 106, 407-443.

Barro, R., Sala-i-Martin, X., 1995. Economic growth. McGraw-Hill, New York.

Bassanini, A., Scarpetta, S., 2001. The driving forces of economic growth: panel data evidence for the OECD countries. OECD Economic Studies 33 (II), 9--

Bassanini, A., Scarpetta, S., Hemmings, P., 2001. Economic growth: the role of policies and institutions. Panel data evidence from OECD countries. Economics Department Working Papers No. 283. OECD, Paris.

Blanchard, O., Perotti, R., 2002. An empirical characterization of the dynamic effects of changes in government spending and taxes on output. The Quarterly Journal of Economics, 117, $1329-1368$.

Bloom, D., Canning, D., Mansfield, R., Moore, M., 2007. Demographic change, social security systems, and savings. Journal of Monetary Economics, 54(1), 92-114.

Blundell R., Bond, S., 1998. Initial conditions and moment restrictions in dynamic panel data models. Journal of Econometrics, 87(1), 115-143.

Bruno, G., 2005a. Estimation and inference in dynamic unbalanced panel-data models with a small number of individuals. Stata Journal, 5(4), 473-500.

Bruno, G., 2005b. Approximating the bias of the LSDV estimator for dynamic unbalanced panel data models. Economics Letters, 87(3), 361-366.

Castro, V., 2016. On the behaviour of the functional components of government expenditures during fiscal consolidation. NIPE Working Paper, WP 11/2016, University of Minho, Portugal. 
Cimadomo, J., Kirchner, M., and S. Hauptmeier, 2010. Transmission of government spending shocks in the euro area: Time variation and driving forces. European Central Bank, ECB Working Paper No. 1219.

Cugnasca, A., Rother, P., 2015. Fiscal multipliers during consolidation: evidence from the European Union. ECB Working Paper 1863.

Dellepiane, S., Hardiman, N., 2012. Fiscal politics in time: Pathways to fiscal consolidation, 1980-2012.UCD Geary Institute Discussion Paper Series, WP2012/28.

Devries, P., Guajardo, J., Leigh, D., Pescatori, A., 2011. A new action based dataset of fiscal consolidation. International Monetary Fund, IMF Working Paper No. 128.

Erceg, C., Linde, J., 2013. Fiscal Consolidation in a Currency Union: Spending Cuts vs Tax Hikes. Journal of Economic Dynamics and Control, 37 (2), 422-45.

Easterly, W., Rodriguez, C., Schmidt-Hebbel, K., 1994. Public sector deficits and macroeconomic performance. The World Bank, Washington.

Forni, L., Gerali, A., Pisani, M., 2010. The Macroeconomics of Fiscal Consolidations in Euro Area Countries. Journal of Economic Dynamics and Control, 34 (9), 1791-1812.

Furceri, D., Jalles, J., Loungani, P., 2015. Fiscal consolidation and inequality in advanced economies: How robust is the link? Paper presented at the 17th Conference on Public Finances "Beyond the austerity dispute: New priorities for fiscal policy". Banca d'Italia, Perugia, 9-11 April 2015 (http://www.bancaditalia.it/pubblicazioni /altri-atti-convegni/2015-beyond-austerity/Furceri_TovarJalles_Loungani.pdf).

Giavazzi, F., Pagano, M., 1990. Can severe fiscal contractions be expansionary? Tales of two small European countries. NBER Macroeconomics Annual, 95-122, MIT Press. 
Gupta, S., Clements, B., Baldacci, E., Mulas-Granados, C., 2005. Fiscal policy, expenditure composition, and growth in low-income countries. Journal of International Money and Finance, 24, 441-463.

Heylen, F., Hoebeeck, A., Buyse, T., 2013. Government efficiency, institutions, and the effects of fiscal consolidation on public debt. European Journal of Political Economy, 31, $40-59$.

Kataryniuk, I., Vallés, J., 2015. Fiscal consolidation after the Great Recession: The role of composition. Bank of Spain Working-Paper 1515.

McDermott, C., Wescott, R., 1996. An empirical analysis of fiscal adjustments. IMF Staff Papers, 43(4), 725-753.

Miller, S., Russek, F., 2003. The relationship between large fiscal adjustments and short-term output growth under alternative fiscal policy regimes. Contemporary Economic Policy, 21, 41-58.

Mulas-Granados, C., 2005. Fiscal adjustments and the short-term trade-off between economic growth and equality. Hacienda Pública Española / Revista de Economia Pública, 172(1), $61-92$.

Nolan, B., Marx, I., Salverda, W., 2011. Comparable indicators of inequality across countries. GINI Discussion Paper No. 9.

OECD, 2015. Government at a Glance 2013. OECD Publishing, Paris.

OECD, 2011. Restoring Public Finances. Special Issue of the OECD Journal on Budgeting, Volume 2011/2, OECD Publishing, Paris.

Perotti, R., 1999. Fiscal policy in good times and bad. The Quarterly Journal of Economics, 114, 1399-1436.

Perotti, R., 2011. The "austerity myth": gain without pain? CEPR Discussion Paper, Nº 8658. 
Roodman, D., 2009. How to do xtabond2: An introduction to difference and system GMM in Stata. Stata Journal, 9(1), 86-136.

Silva, R., Carvalho, V., Ribeiro, A., 2013. How large are fiscal multipliers? A panel-data VAR approach for the Euro Area. FEP Working Papers 500, Faculty of Economics, University of Porto.

Solt, F., 2009. Standardizing the World Income Inequality Database. Social Science Quarterly, 90(2), 231-242.

Turrini, A., 2013. Fiscal consolidation and unemployment: does EPL matter? A look at EU countries. IZA Journal of Labor Policy 2: 8. 


\section{Tables}

Table 1. Expenditure components, fiscal consolidations and GDP growth

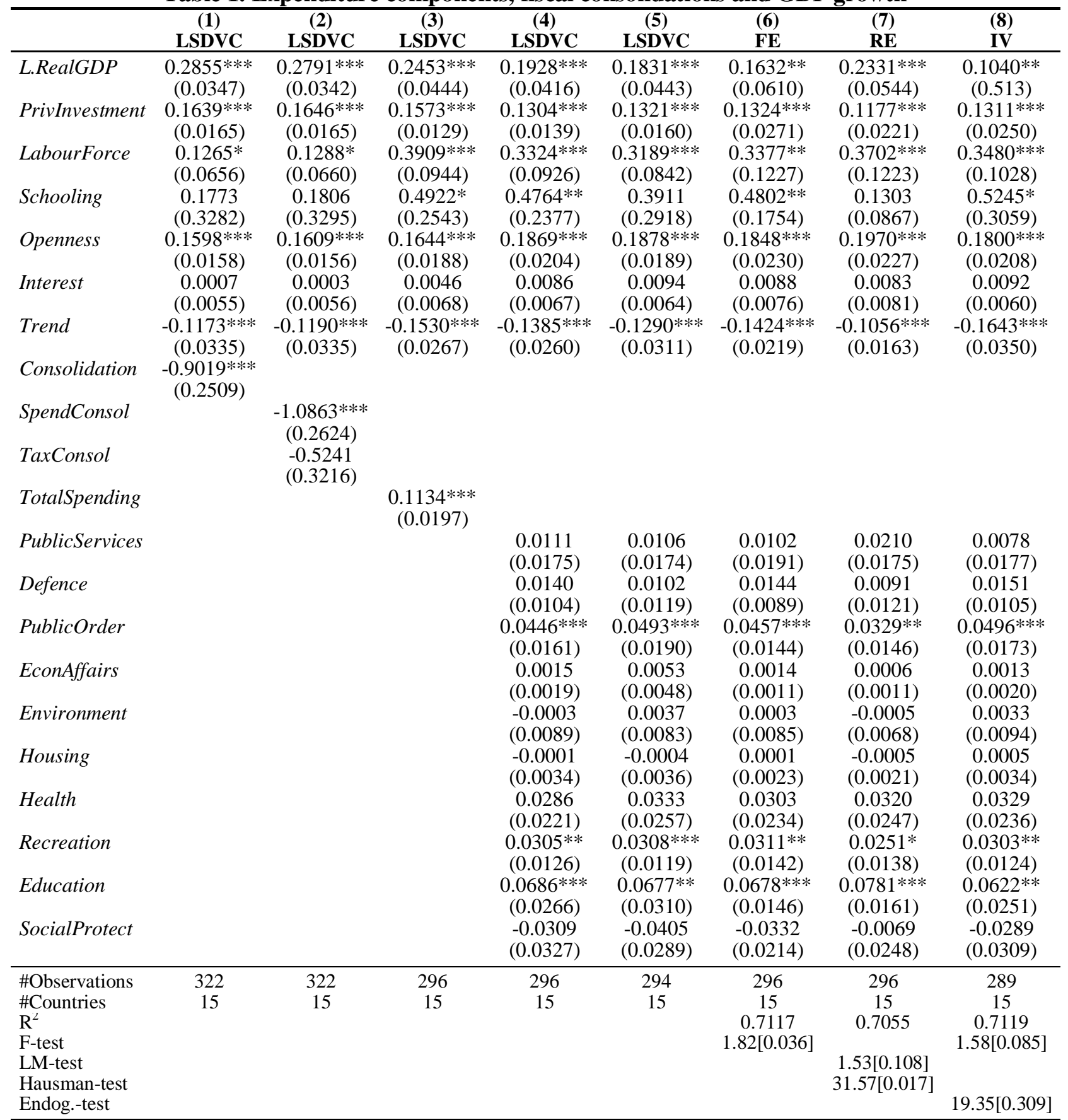

Notes: Standard errors are in parentheses; significance level at which the null hypothesis is rejected: ***, 1\%; **, 5\%; and *, 10\%. All variables are in growth rates (except Schooling); in regression 5, the expenditure components are in growth rates of their per capita values. The bias-corrected least squares dummy variable (LSDVC) estimator developed by Bruno's (2005a, b) is employed in regressions $1-5 ; 50$ repetitions of the procedure are run to bootstrap the estimated standard errors. Fixed and random effects estimators are used in regressions 6 and 7, respectively, while a fixed-effects IV estimator is employed in regression 8. The F, LM and Hausman panel data test-statistics and the endogeneity Durbin-Wu-Hausman chi-square test-statistic are reported at the bottom of the table (the respective p-values in square brackets). 
Table 2. Effects on GDP growth: PIIGS versus the other countries

\begin{tabular}{|c|c|c|c|c|c|c|c|c|}
\hline & \multicolumn{4}{|c|}{ PIIGS } & \multicolumn{4}{|c|}{ Other Countries } \\
\hline & (1) & $(2)$ & (3) & (4) & $(1)$ & (2) & (3) & $(4)$ \\
\hline L.RealGDP & $\begin{array}{c}0.4550 * * * \\
(0.0740)\end{array}$ & $\begin{array}{c}0.4542 * * * \\
(0.0732)\end{array}$ & $\begin{array}{c}0.4456 * * * \\
(0.0751)\end{array}$ & $\begin{array}{c}0.2801 * * * \\
(0.0849)\end{array}$ & $\begin{array}{c}0.1087 * * \\
(0.0453)\end{array}$ & $\begin{array}{c}0.0969 * * \\
(0.0443)\end{array}$ & $\begin{array}{c}0.0808 \\
(0.0559)\end{array}$ & $\begin{array}{l}0.1035^{*} \\
(0.0597)\end{array}$ \\
\hline PrivInvestment & $\begin{array}{c}0.1376 * * * \\
(0.0247)\end{array}$ & $\begin{array}{c}0.1365 * * * \\
(0.0258)\end{array}$ & $\begin{array}{c}0.1452 * * * \\
(0.0238)\end{array}$ & $\begin{array}{c}0.1297 * * * \\
(0.0231)\end{array}$ & $\begin{array}{c}0.1771 * * * \\
(0.0210)\end{array}$ & $\begin{array}{c}0.1772 * * * \\
(0.0209)\end{array}$ & $\begin{array}{c}0.1558 * * * \\
(0.0180)\end{array}$ & $\begin{array}{c}0.1242 * * * \\
(0.0202)\end{array}$ \\
\hline LabourForce & $\begin{array}{c}0.3599 * * \\
(0.1474)\end{array}$ & $\begin{array}{c}0.3725^{* *} \\
(0.1513)\end{array}$ & $\begin{array}{c}0.4495 * * * \\
(0.1694)\end{array}$ & $\begin{array}{c}0.4979 * * * \\
(0.1473)\end{array}$ & $\begin{array}{c}0.0216 \\
(0.0709)\end{array}$ & $\begin{array}{c}0.0374 \\
(0.0707)\end{array}$ & $\begin{array}{l}0.2297 * \\
(0.1207)\end{array}$ & $\begin{array}{c}0.1873 \\
(0.1266)\end{array}$ \\
\hline Schooling & $\begin{array}{c}0.0525 \\
(0.5376)\end{array}$ & $\begin{array}{c}0.0661 \\
(0.5482)\end{array}$ & $\begin{array}{l}-0.0858 \\
(0.7362)\end{array}$ & $\begin{array}{l}-0.0264 \\
(0.7027)\end{array}$ & $\begin{array}{c}0.3465 \\
(0.3344)\end{array}$ & $\begin{array}{c}0.3740 \\
(0.3317)\end{array}$ & $\begin{array}{c}0.7833 * * \\
(0.3499)\end{array}$ & $\begin{array}{l}0.6096^{*} \\
(0.3500)\end{array}$ \\
\hline Openness & $\begin{array}{c}0.1230 * * * \\
(0.0268)\end{array}$ & $\begin{array}{c}0.1225 * * * \\
(0.0271)\end{array}$ & $\begin{array}{c}0.1037 * * * \\
(0.0229)\end{array}$ & $\begin{array}{c}0.1398 * * * \\
(0.0274)\end{array}$ & $\begin{array}{c}0.1628 * * * \\
(0.0177)\end{array}$ & $\begin{array}{c}0.1650 * * * \\
(0.0175)\end{array}$ & $\begin{array}{c}0.1956 * * * \\
(0.0204)\end{array}$ & $\begin{array}{c}0.2046 * * * \\
(0.0217)\end{array}$ \\
\hline Interest & $\begin{array}{l}-0.0016 \\
(0.0093)\end{array}$ & $\begin{array}{l}-0.0013 \\
(0.0093)\end{array}$ & $\begin{array}{c}0.0062 \\
(0.0088)\end{array}$ & $\begin{array}{c}0.0079 \\
(0.0090)\end{array}$ & $\begin{array}{c}0.0263 * * * \\
(0.0096)\end{array}$ & $\begin{array}{c}0.0261 * * * \\
(0.0095)\end{array}$ & $\begin{array}{c}0.0259 * * * \\
(0.0087)\end{array}$ & $\begin{array}{c}0.0269 * * * \\
(0.0081)\end{array}$ \\
\hline Trend & $\begin{array}{l}-0.0862 \\
(0.0681)\end{array}$ & $\begin{array}{l}-0.0876 \\
(0.0691)\end{array}$ & $\begin{array}{c}-0.0948 \\
(0.0726)\end{array}$ & $\begin{array}{l}-0.0908 \\
(0.0719)\end{array}$ & $\begin{array}{c}-0.1207 * * * \\
(0.0312)\end{array}$ & $\begin{array}{c}-0.1267 * * * \\
(0.0311)\end{array}$ & $\begin{array}{c}-0.1641^{* * * *} \\
(0.0364)\end{array}$ & $\begin{array}{c}-0.1354 * * * \\
(0.0363)\end{array}$ \\
\hline Consolidation & $\begin{array}{c}-1.0567 * * \\
(0.4585)\end{array}$ & & & & $\begin{array}{c}-0.4440^{*} \\
(0.2622)\end{array}$ & & & \\
\hline SpendConsol & & $\begin{array}{c}-1.0067 * * \\
(0.5052)\end{array}$ & & & & $\begin{array}{c}-0.7224 * * \\
(0.3191)\end{array}$ & & \\
\hline TaxConsol & & $\begin{array}{c}-1.1738 * * \\
(0.5707)\end{array}$ & & & & $\begin{array}{c}0.0315 \\
(0.3690)\end{array}$ & & \\
\hline TotalSpending & & & $\begin{array}{c}0.0928 * * * \\
(0.0298)\end{array}$ & & & & $\begin{array}{c}0.1219 * * * \\
(0.0237)\end{array}$ & \\
\hline PublicServices & & & & $\begin{array}{c}0.0165 \\
(0.0294)\end{array}$ & & & & $\begin{array}{c}0.0158 \\
(0.0236)\end{array}$ \\
\hline Defence & & & & $\begin{array}{l}-0.0085 \\
(0.0232)\end{array}$ & & & & $\begin{array}{c}0.0123 \\
(0.0131)\end{array}$ \\
\hline PublicOrder & & & & $\begin{array}{c}0.0389 * * \\
(0.0190)\end{array}$ & & & & $\begin{array}{c}0.0630 * * \\
(0.0309)\end{array}$ \\
\hline EconAffairs & & & & $\begin{array}{c}0.0058 \\
(0.0055)\end{array}$ & & & & $\begin{array}{c}0.0009 \\
(0.0018)\end{array}$ \\
\hline Environment & & & & $\begin{array}{c}0.0492 * * \\
(0.0209)\end{array}$ & & & & $\begin{array}{l}-0.0068 \\
(0.0087)\end{array}$ \\
\hline Housing & & & & $\begin{array}{c}0.0016 \\
(0.0040)\end{array}$ & & & & $\begin{array}{l}-0.0059 \\
(0.0080)\end{array}$ \\
\hline Health & & & & $\begin{array}{c}0.0351 \\
(0.0333)\end{array}$ & & & & $\begin{array}{l}-0.0251 \\
(0.0370)\end{array}$ \\
\hline Recreation & & & & $\begin{array}{l}-0.0032 \\
(0.0157)\end{array}$ & & & & $\begin{array}{l}0.0518 * * \\
(0.0201)\end{array}$ \\
\hline Education & & & & $\begin{array}{c}0.0470 * * \\
(0.0217)\end{array}$ & & & & $\begin{array}{c}0.0657 \\
(0.0444)\end{array}$ \\
\hline SocialProtect & & & & $\begin{array}{l}-0.0011 \\
(0.0443)\end{array}$ & & & & $\begin{array}{l}-0.0280 \\
(0.0497)\end{array}$ \\
\hline \#Observations & 105 & 105 & 100 & 100 & 217 & 217 & 196 & 196 \\
\hline \#Countries & 5 & 5 & 5 & 5 & 10 & 10 & 10 & 10 \\
\hline
\end{tabular}

Notes: See Table 1. Estimates obtained using the LSDVC estimator; 50 repetitions of the procedure are run to bootstrap the estimated standard errors, reported in parentheses; significance level at which the null hypothesis is rejected: ***, 1\%; **, 5\%; and $*, 10 \%$. All variables are in growth rates (except Schooling). 
Table 3. Expenditure components, fiscal consolidations and unemployment

\begin{tabular}{|c|c|c|c|c|c|c|c|c|}
\hline & $\begin{array}{c}(1) \\
\text { LSDVC }\end{array}$ & $\begin{array}{c}(2) \\
\text { LSDVC }\end{array}$ & $\begin{array}{c}\text { (3) } \\
\text { LSDVC }\end{array}$ & $\begin{array}{c}\text { (4) } \\
\text { LSDVC }\end{array}$ & $\begin{array}{c}5) \\
\text { LSDVC } \\
\end{array}$ & (6) & $\begin{array}{l}\text { (7) } \\
\text { RE } \\
\end{array}$ & $\begin{array}{l}\text { (8) } \\
\text { IV }\end{array}$ \\
\hline L.Unemp & $\begin{array}{c}0.3867 * * * \\
(0.0474)\end{array}$ & $\begin{array}{c}0.3832 * * * \\
(0.0484)\end{array}$ & $\begin{array}{c}0.3984 * * * \\
(0.0469)\end{array}$ & $\begin{array}{c}0.3215 * * * \\
(0.0469)\end{array}$ & $\begin{array}{c}0.3261 * * * \\
(0.0459)\end{array}$ & $\begin{array}{c}0.2825 * * \\
(0.1027)\end{array}$ & $\begin{array}{c}0.3169 * * * \\
(0.1076)\end{array}$ & $\begin{array}{c}0.4274 * * * \\
(0.0863)\end{array}$ \\
\hline OutputGap & $\begin{array}{c}-0.7864 * * \\
(0.3275)\end{array}$ & $\begin{array}{c}-0.7453 * * \\
(0.3192)\end{array}$ & $\begin{array}{c}-0.6877 * * \\
(0.2714)\end{array}$ & $\begin{array}{c}-0.8266 * * * \\
(0.2591)\end{array}$ & $\begin{array}{c}-0.7555 * * \\
(0.3024)\end{array}$ & $\begin{array}{c}-0.8843 * * * \\
(0.2599)\end{array}$ & $\begin{array}{c}-0.6711 * * * \\
(0.2410)\end{array}$ & $\begin{array}{c}-0.5824^{*} \\
(0.3205)\end{array}$ \\
\hline PrivInvestment & $\begin{array}{c}-0.9485^{* * * *} \\
(0.1098)\end{array}$ & $\begin{array}{c}-0.9523 * * * \\
(0.1093)\end{array}$ & $\begin{array}{c}-0.8802 * * * \\
(0.0987)\end{array}$ & $\begin{array}{c}-0.7590 * * * \\
(0.1022)\end{array}$ & $\begin{array}{c}-0.7823 * * * \\
(0.1197)\end{array}$ & $\begin{array}{c}-0.7734 * * * \\
(0.1939)\end{array}$ & $\begin{array}{c}-0.7862 * * * \\
(0.1855)\end{array}$ & $\begin{array}{c}-0.6732 * * * \\
(0.1409)\end{array}$ \\
\hline Schooling & $\begin{array}{l}-2.9787 \\
(2.2798)\end{array}$ & $\begin{array}{l}-2.9198 \\
(2.3053)\end{array}$ & $\begin{array}{l}-4.1236 \\
(2.6471)\end{array}$ & $\begin{array}{l}-3.7063 \\
(2.6089)\end{array}$ & $\begin{array}{l}-3.0121 \\
(2.1443)\end{array}$ & $\begin{array}{c}-3.9376 * * \\
(1.7963)\end{array}$ & $\begin{array}{c}0.1282 \\
(0.3560)\end{array}$ & $\begin{array}{l}-2.1736 \\
(2.5377)\end{array}$ \\
\hline Openness & $\begin{array}{c}-0.6837 * * * \\
(0.1496)\end{array}$ & $\begin{array}{c}-0.6950 * * * \\
(0.1485)\end{array}$ & $\begin{array}{c}-0.7477 * * * \\
(0.1355)\end{array}$ & $\begin{array}{c}-0.7111 * * * \\
(0.1500)\end{array}$ & $\begin{array}{c}-0.7145 * * * \\
(0.1313)\end{array}$ & $\begin{array}{c}-0.6846 * * * \\
(0.1670)\end{array}$ & $\begin{array}{c}-0.7056 * * * \\
(0.1657)\end{array}$ & $\begin{array}{c}-0.8387 * * * \\
(0.1591)\end{array}$ \\
\hline Wages & $\begin{array}{c}0.5487 \\
(0.5015)\end{array}$ & $\begin{array}{c}0.5392 \\
(0.4970)\end{array}$ & $\begin{array}{c}1.1553 * * \\
(0.5113)\end{array}$ & $\begin{array}{c}1.4667 * * * \\
(0.5551)\end{array}$ & $\begin{array}{c}1.6464 * * * \\
(0.4042)\end{array}$ & $\begin{array}{c}1.4448 \\
(0.8964)\end{array}$ & $\begin{array}{c}1.2160 \\
(0.8199)\end{array}$ & $\begin{array}{c}1.5587 * * * \\
(0.4737)\end{array}$ \\
\hline Trend & $\begin{array}{c}0.5823^{* *} \\
(0.2715)\end{array}$ & $\begin{array}{c}0.5832 * * \\
(0.2750)\end{array}$ & $\begin{array}{c}0.7251 * * * \\
(0.2614)\end{array}$ & $\begin{array}{c}0.6205^{* *} \\
(0.2571)\end{array}$ & $\begin{array}{c}0.5530^{* * *} \\
(0.2658)\end{array}$ & $\begin{array}{c}0.6456^{* * *} \\
(0.2563)\end{array}$ & $\begin{array}{l}0.2825^{*} \\
(0.1717)\end{array}$ & $\begin{array}{l}0.4701 * \\
(0.2722)\end{array}$ \\
\hline Consolidation & $\begin{array}{c}2.3892 * * \\
(1.2160)\end{array}$ & & & & & & & \\
\hline SpendConsol & & $\begin{array}{c}3.9581 * * \\
(2.0052)\end{array}$ & & & & & & \\
\hline TaxConsol & & $\begin{array}{c}0.7217 \\
(2.5458)\end{array}$ & & & & & & \\
\hline TotalSpending & & & $\begin{array}{c}-0.6666 * * * \\
(0.1453)\end{array}$ & & & & & \\
\hline PublicServices & & & & $\begin{array}{c}0.0727 \\
(0.1259)\end{array}$ & $\begin{array}{c}0.0520 \\
(0.1338)\end{array}$ & $\begin{array}{c}0.0748 \\
(0.1645)\end{array}$ & $\begin{array}{c}0.1080 \\
(0.1789)\end{array}$ & $\begin{array}{c}0.0592 \\
(0.1373)\end{array}$ \\
\hline Defence & & & & $\begin{array}{c}-0.2459 * * * \\
(0.0740)\end{array}$ & $\begin{array}{c}-0.2500 * * * \\
(0.0718)\end{array}$ & $\begin{array}{c}-0.2430 * * * \\
(0.0745)\end{array}$ & $\begin{array}{c}-0.2598 * * * \\
(0.0830)\end{array}$ & $\begin{array}{c}-0.2815^{* * *} \\
(0.0865)\end{array}$ \\
\hline PublicOrder & & & & $\begin{array}{c}-0.3145 * * \\
(0.1335)\end{array}$ & $\begin{array}{c}-0.4057 * * \\
(0.1681)\end{array}$ & $\begin{array}{c}-0.3131 * * \\
(0.1399)\end{array}$ & $\begin{array}{c}-0.2316^{*} \\
(0.1336)\end{array}$ & $\begin{array}{c}-0.3683 * * \\
(0.1455)\end{array}$ \\
\hline EconAffairs & & & & $\begin{array}{l}-0.0059 \\
(0.0155)\end{array}$ & $\begin{array}{c}-0.0726 * * \\
(0.0341)\end{array}$ & $\begin{array}{l}-0.0055 \\
(0.0276)\end{array}$ & $\begin{array}{l}-0.0043 \\
(0.0292)\end{array}$ & $\begin{array}{l}-0.0080 \\
(0.0149)\end{array}$ \\
\hline Environment & & & & $\begin{array}{l}-0.0596 \\
(0.0574)\end{array}$ & $\begin{array}{l}-0.0677 \\
(0.0511)\end{array}$ & $\begin{array}{l}-0.0623 \\
(0.0791)\end{array}$ & $\begin{array}{l}-0.0795 \\
(0.0764)\end{array}$ & $\begin{array}{l}-0.0650 \\
(0.0693)\end{array}$ \\
\hline Housing & & & & $\begin{array}{l}-0.0125 \\
(0.0244)\end{array}$ & $\begin{array}{l}-0.0008 \\
(0.0298)\end{array}$ & $\begin{array}{l}-0.0143 \\
(0.0101)\end{array}$ & $\begin{array}{l}-0.0144 \\
(0.0093)\end{array}$ & $\begin{array}{l}-0.0039 \\
(0.0253)\end{array}$ \\
\hline Health & & & & $\begin{array}{l}-0.0986 \\
(0.1735)\end{array}$ & $\begin{array}{l}-0.1038 \\
(0.1803)\end{array}$ & $\begin{array}{l}-0.1170 \\
(0.1353)\end{array}$ & $\begin{array}{l}-0.1582 \\
(0.1407)\end{array}$ & $\begin{array}{l}-0.0165 \\
(0.1883)\end{array}$ \\
\hline Recreation & & & & $\begin{array}{l}-0.0204 \\
(0.0764)\end{array}$ & $\begin{array}{l}-0.0098 \\
(0.0982)\end{array}$ & $\begin{array}{l}-0.0260 \\
(0.0736)\end{array}$ & $\begin{array}{l}-0.0029 \\
(0.0682)\end{array}$ & $\begin{array}{c}0.0099 \\
(0.0962)\end{array}$ \\
\hline Education & & & & $\begin{array}{c}-0.4262 * * \\
(0.1766)\end{array}$ & $\begin{array}{c}-0.3830^{*} \\
(0.2299)\end{array}$ & $\begin{array}{c}-0.4223^{*} \\
(0.2226)\end{array}$ & $\begin{array}{l}-0.3926^{*} \\
(0.2033)\end{array}$ & $\begin{array}{c}-0.3369^{*} \\
(0.1980)\end{array}$ \\
\hline SocialProtect & & & & $\begin{array}{c}0.5531 * * \\
(0.2316)\end{array}$ & $\begin{array}{c}0.6117 * * * \\
(0.2180)\end{array}$ & $\begin{array}{c}0.5766^{* *} * \\
(0.2205)\end{array}$ & $\begin{array}{c}0.6543 * * * \\
(0.2291)\end{array}$ & $\begin{array}{c}0.4448 \\
(0.3371)\end{array}$ \\
\hline \#Observations & 302 & 302 & 282 & 282 & 280 & 282 & 282 & 274 \\
\hline $\begin{array}{l}\text { \#Countries } \\
\mathrm{R}^{2}\end{array}$ & 15 & 15 & 15 & 15 & 15 & $\begin{array}{c}15 \\
05911\end{array}$ & $\begin{array}{c}15 \\
08834\end{array}$ & $\begin{array}{c}15 \\
05509\end{array}$ \\
\hline $\begin{array}{l}\mathrm{R}^{2} \\
\text { F-test }\end{array}$ & & & & & & $\begin{array}{c}0.5911 \\
1.78[0.042]\end{array}$ & 0.5834 & $\begin{array}{c}0.5509 \\
1.64[0.069]\end{array}$ \\
\hline LM-test & & & & & & & $0.98[0.321]$ & \\
\hline $\begin{array}{l}\text { Hausman-test } \\
\text { Endog.-test }\end{array}$ & & & & & & & $27.99[0.045]$ & $26.55[0.065]$ \\
\hline
\end{tabular}

Notes: See Table 1. All variables in growth rates (except Schooling and OutputGap); in regression 5, the expenditure components are in growth rates of their per capita values. 
Table 4. Effects on unemployment: PIIGS versus the other countries

\begin{tabular}{|c|c|c|c|c|c|c|c|c|}
\hline & \multicolumn{4}{|c|}{ PIIGS } & \multicolumn{4}{|c|}{ Other countries } \\
\hline & (1) & (2) & (3) & (4) & (1) & (2) & (3) & (4) \\
\hline L.Unemp & $\begin{array}{l}0.1839 * \\
(0.1116)\end{array}$ & $\begin{array}{c}0.1790 \\
(0.1104)\end{array}$ & $\begin{array}{c}0.3233 * * * \\
(0.0949)\end{array}$ & $\begin{array}{c}0.1803 * * \\
(0.0827)\end{array}$ & $\begin{array}{c}0.4137 * * * \\
(0.0506)\end{array}$ & $\begin{array}{c}0.4063 * * * \\
(0.0506)\end{array}$ & $\begin{array}{c}0.3949 * * * \\
(0.0510)\end{array}$ & $\begin{array}{c}0.3975 * * * \\
(0.0553)\end{array}$ \\
\hline OutputGap & $\begin{array}{l}-0.7004 \\
(0.5587)\end{array}$ & $\begin{array}{l}-0.7366 \\
(0.5627)\end{array}$ & $\begin{array}{l}-0.4602 \\
(0.4212)\end{array}$ & $\begin{array}{c}-0.7329 * \\
(0.3926)\end{array}$ & $\begin{array}{c}-1.3228 * * * \\
(0.4838)\end{array}$ & $\begin{array}{c}-1.2115^{* * *} \\
(0.4701)\end{array}$ & $\begin{array}{c}-1.2491 * * * \\
(0.3706)\end{array}$ & $\begin{array}{c}-1.2102 * * * \\
(0.3952)\end{array}$ \\
\hline PrivInvestment & $\begin{array}{c}-0.8432 * * * \\
(0.2061)\end{array}$ & $\begin{array}{c}-0.8343 * * * \\
(0.2085)\end{array}$ & $\begin{array}{c}-0.8579 * * * \\
(0.2268)\end{array}$ & $\begin{array}{c}-0.8728 * * * \\
(0.2401)\end{array}$ & $\begin{array}{c}-0.8836 * * * \\
(0.1409)\end{array}$ & $\begin{array}{c}-0.9027 * * * \\
(0.1374)\end{array}$ & $\begin{array}{c}-0.7729 * * * \\
(0.1386)\end{array}$ & $\begin{array}{c}-0.6692 * * * \\
(0.1513)\end{array}$ \\
\hline Schooling & $\begin{array}{l}-0.0706 \\
(5.3252)\end{array}$ & $\begin{array}{l}-0.5829 \\
(5.3500)\end{array}$ & $\begin{array}{c}2.2158 \\
(9.2457)\end{array}$ & $\begin{array}{c}2.3448 \\
(7.9113)\end{array}$ & $\begin{array}{c}-4.5939 * \\
(2.6184)\end{array}$ & $\begin{array}{l}-4.6809 * \\
(2.8243)\end{array}$ & $\begin{array}{c}-5.8162 * * \\
(2.7868)\end{array}$ & $\begin{array}{l}-4.1878^{*} \\
(2.5684)\end{array}$ \\
\hline Openness & $\begin{array}{l}-0.4936^{*} \\
(0.2575)\end{array}$ & $\begin{array}{r}-0.4875^{*} \\
(0.2586)\end{array}$ & $\begin{array}{l}-0.3913 \\
(0.2457)\end{array}$ & $\begin{array}{l}-0.2838 \\
(0.2739)\end{array}$ & $\begin{array}{c}-0.7319 * * * \\
(0.1618)\end{array}$ & $\begin{array}{c}-0.7598 * * * \\
(0.1553)\end{array}$ & $\begin{array}{c}-0.8791 * * * \\
(0.1431)\end{array}$ & $\begin{array}{c}-0.8281 * * * \\
(0.1485)\end{array}$ \\
\hline Wages & $\begin{array}{c}1.3529 \\
(0.8484)\end{array}$ & $\begin{array}{c}1.3933 \\
(0.8561)\end{array}$ & $\begin{array}{l}1.7116 * * \\
(0.6929)\end{array}$ & $\begin{array}{l}1.6637 * * \\
(0.6613)\end{array}$ & $\begin{array}{c}0.5285 \\
(0.5509)\end{array}$ & $\begin{array}{c}0.5015 \\
(0.5472)\end{array}$ & $\begin{array}{l}1.0879 * * \\
(0.5489)\end{array}$ & $\begin{array}{c}1.5100 * * * \\
(0.5633)\end{array}$ \\
\hline Trend & $\begin{array}{c}0.9122 \\
(0.6759)\end{array}$ & $\begin{array}{c}0.9742 \\
(0.6755)\end{array}$ & $\begin{array}{c}0.7288 \\
(0.8173)\end{array}$ & $\begin{array}{c}0.3447 \\
(0.7432)\end{array}$ & $\begin{array}{c}0.5913 * * \\
(0.3005)\end{array}$ & $\begin{array}{c}0.6224 * * \\
(0.3069)\end{array}$ & $\begin{array}{c}0.7187 * * \\
(0.2952)\end{array}$ & $\begin{array}{c}0.5795 * * \\
(0.2802)\end{array}$ \\
\hline Consolidation & $\begin{array}{c}10.5481 * * \\
(4.5658)\end{array}$ & & & & $\begin{array}{l}-1.0613 \\
(1.9077)\end{array}$ & & & \\
\hline SpendConsol & & $\begin{array}{c}9.3050 * * \\
(4.7118)\end{array}$ & & & & $\begin{array}{c}1.5768 \\
(2.0916)\end{array}$ & & \\
\hline TaxConsol & & $\begin{array}{c}13.3083 * * \\
(5.8949)\end{array}$ & & & & $\begin{array}{l}-3.6836 \\
(2.4872)\end{array}$ & & \\
\hline TotalSpending & & & $\begin{array}{c}-0.7361 * * \\
(0.3042)\end{array}$ & & & & $\begin{array}{c}-0.6251 * * * \\
(0.2120)\end{array}$ & \\
\hline PublicServices & & & & $\begin{array}{c}0.5572 \\
(0.3608)\end{array}$ & & & & $\begin{array}{l}-0.1636 \\
(0.1315)\end{array}$ \\
\hline Defence & & & & $\begin{array}{c}-0.5869 * * * \\
(0.2063)\end{array}$ & & & & $\begin{array}{c}-0.1690 * * \\
(0.0799)\end{array}$ \\
\hline PublicOrder & & & & $\begin{array}{l}-0.0762 \\
(0.2444)\end{array}$ & & & & $\begin{array}{c}-0.3180 * * \\
(0.1492)\end{array}$ \\
\hline EconAffairs & & & & $\begin{array}{c}-0.1323 * * * \\
(0.0469)\end{array}$ & & & & $\begin{array}{c}0.0150 \\
(0.0152)\end{array}$ \\
\hline Environment & & & & $\begin{array}{c}-0.3434 * \\
(0.1806)\end{array}$ & & & & $\begin{array}{c}0.0150 \\
(0.0625)\end{array}$ \\
\hline Housing & & & & $\begin{array}{l}-0.0047 \\
(0.0345)\end{array}$ & & & & $\begin{array}{c}0.0129 \\
(0.0543)\end{array}$ \\
\hline Health & & & & $\begin{array}{l}-0.4359 \\
(0.3472)\end{array}$ & & & & $\begin{array}{c}0.0637 \\
(0.1948)\end{array}$ \\
\hline Recreation & & & & $\begin{array}{c}0.0229 \\
(0.1286)\end{array}$ & & & & $\begin{array}{l}-0.0193 \\
(0.1456)\end{array}$ \\
\hline Education & & & & $\begin{array}{c}0.1101 \\
(0.2973)\end{array}$ & & & & $\begin{array}{c}-0.5201 * * \\
(0.2313)\end{array}$ \\
\hline SocialProtect & & & & $\begin{array}{r}0.9230 * * \\
(0.4567)\end{array}$ & & & & $\begin{array}{c}0.3885 \\
(0.3838)\end{array}$ \\
\hline \#Observations & 92 & 92 & 88 & 88 & 210 & 210 & 194 & 194 \\
\hline \#Countries & 5 & 5 & 5 & 5 & 10 & 10 & 10 & 10 \\
\hline
\end{tabular}

Notes: See Table 3. Estimates obtained using the LSDVC estimator; 50 repetitions of the procedure are run to bootstrap the estimated standard errors, reported in parentheses; significance level at which the null hypothesis is rejected: ***, 1\%; **, 5\%; and *, 10\%. All variables are in growth rates (except Schooling and OutputGap). 
Table 5. Expenditure components, fiscal consolidations and inequality

\begin{tabular}{|c|c|c|c|c|c|c|c|c|}
\hline & $\begin{array}{c}\text { (1) } \\
\text { LSDVC }\end{array}$ & $\begin{array}{c}(2) \\
\text { LSDVC }\end{array}$ & $\begin{array}{c}\text { (3) } \\
\text { LSDVC }\end{array}$ & $\begin{array}{c}\text { (4) } \\
\text { LSDVC }\end{array}$ & $\begin{array}{c}\text { (5) } \\
\text { LSDVC }\end{array}$ & (6) & $\begin{array}{l}\text { (7) } \\
\text { RE }\end{array}$ & $\begin{array}{l}\text { (8) } \\
\text { IV }\end{array}$ \\
\hline L.Gini & $\begin{array}{c}0.3619 * * * \\
(0.0542)\end{array}$ & $\begin{array}{c}0.3609 * * * \\
(0.0529)\end{array}$ & $\begin{array}{c}0.3456 * * * \\
(0.0517)\end{array}$ & $\begin{array}{c}0.3311 * * * \\
(0.0517)\end{array}$ & $\begin{array}{c}0.3278 * * * \\
(0.0583)\end{array}$ & $\begin{array}{c}0.2687 * * * \\
(0.0815)\end{array}$ & $\begin{array}{c}0.2835 * * * \\
(0.0801)\end{array}$ & $\begin{array}{c}0.0907 \\
(0.2228)\end{array}$ \\
\hline RealGDPpc & $\begin{array}{c}-0.2801 * * * \\
(0.0615)\end{array}$ & $\begin{array}{c}-0.2829 * * * \\
(0.0612)\end{array}$ & $\begin{array}{c}-0.3036 * * * \\
(0.0551)\end{array}$ & $\begin{array}{c}-0.2278 * * * \\
(0.0591)\end{array}$ & $\begin{array}{c}-0.2199 * * * \\
(0.0712)\end{array}$ & $\begin{array}{c}-0.2353 * * * \\
(0.0623)\end{array}$ & $\begin{array}{c}-0.2254 * * * \\
(0.0595)\end{array}$ & $\begin{array}{c}-0.2225 * * * \\
(0.0794)\end{array}$ \\
\hline Schooling & $\begin{array}{l}-0.3125 \\
(0.3853)\end{array}$ & $\begin{array}{l}-0.3228 \\
(0.3845)\end{array}$ & $\begin{array}{c}0.0154 \\
(0.5446)\end{array}$ & $\begin{array}{c}0.1616 \\
(0.5558)\end{array}$ & $\begin{array}{c}0.0990 \\
(0.4851)\end{array}$ & $\begin{array}{c}0.1360 \\
(0.5254)\end{array}$ & $\begin{array}{c}-0.1299 * * \\
(0.0649)\end{array}$ & $\begin{array}{c}0.1402 \\
(0.4438)\end{array}$ \\
\hline Openness & $\begin{array}{c}0.0298 \\
(0.0262)\end{array}$ & $\begin{array}{c}0.0315 \\
(0.0260)\end{array}$ & $\begin{array}{c}0.0538 * * \\
(0.0236)\end{array}$ & $\begin{array}{c}0.0379 \\
(0.0288)\end{array}$ & $\begin{array}{c}0.0320 \\
(0.0311)\end{array}$ & $\begin{array}{l}0.0401 * \\
(0.0194)\end{array}$ & $\begin{array}{c}0.0392 * * \\
(0.0188)\end{array}$ & $\begin{array}{c}0.0380 \\
(0.0309)\end{array}$ \\
\hline Wages & $\begin{array}{l}0.0928^{*} \\
(0.0564)\end{array}$ & $\begin{array}{l}0.0948^{*} \\
(0.0564)\end{array}$ & $\begin{array}{l}0.0978^{*} \\
(0.0530)\end{array}$ & $\begin{array}{c}0.1599 * * * \\
(0.0620)\end{array}$ & $\begin{array}{l}0.1490 * \\
(0.0790)\end{array}$ & $\begin{array}{c}0.1581 * * \\
(0.0709)\end{array}$ & $\begin{array}{c}0.1562 * * \\
(0.0659)\end{array}$ & $\begin{array}{c}0.1491 * * \\
(0.0704)\end{array}$ \\
\hline Trend & $\begin{array}{l}-0.0329 \\
(0.0389)\end{array}$ & $\begin{array}{l}-0.0349 \\
(0.0390)\end{array}$ & $\begin{array}{l}-0.0531 \\
(0.0516)\end{array}$ & $\begin{array}{l}-0.0653 \\
(0.0526)\end{array}$ & $\begin{array}{l}-0.0589 \\
(0.0523)\end{array}$ & $\begin{array}{l}-0.0639 \\
(0.0552)\end{array}$ & $\begin{array}{l}-0.0364 \\
(0.0364)\end{array}$ & $\begin{array}{c}-0.0372 \\
(0.0488)\end{array}$ \\
\hline Consolidation & $\begin{array}{l}0.0996^{*} \\
(0.0536)\end{array}$ & & & & & & & \\
\hline SpendConsol & & $\begin{array}{l}0.3022 * \\
(0.1668)\end{array}$ & & & & & & \\
\hline TaxConsol & & $\begin{array}{c}0.3095 \\
(0.4110)\end{array}$ & & & & & & \\
\hline TotalSpending & & & $\begin{array}{l}-0.0469 * \\
(0.0270)\end{array}$ & & & & & \\
\hline PublicServices & & & & $\begin{array}{c}0.0109 \\
(0.0227)\end{array}$ & $\begin{array}{c}0.0127 \\
(0.0274)\end{array}$ & $\begin{array}{c}0.0130 \\
(0.0129)\end{array}$ & $\begin{array}{c}0.0150 \\
(0.0132)\end{array}$ & $\begin{array}{c}0.0245 \\
(0.0261)\end{array}$ \\
\hline Defence & & & & $\begin{array}{l}-0.0053 \\
(0.0144)\end{array}$ & $\begin{array}{l}-0.0016 \\
(0.0135)\end{array}$ & $\begin{array}{l}-0.0045 \\
(0.0096)\end{array}$ & $\begin{array}{l}-0.0044 \\
(0.0094)\end{array}$ & $\begin{array}{l}-0.0072 \\
(0.0150)\end{array}$ \\
\hline PublicOrder & & & & $\begin{array}{l}-0.0193 \\
(0.0336)\end{array}$ & $\begin{array}{l}-0.0226 \\
(0.0318)\end{array}$ & $\begin{array}{l}-0.0191 \\
(0.0194)\end{array}$ & $\begin{array}{l}-0.0173 \\
(0.0182)\end{array}$ & $\begin{array}{l}-0.0060 \\
(0.0347)\end{array}$ \\
\hline EconAffairs & & & & $\begin{array}{c}0.0022 \\
(0.0021)\end{array}$ & $\begin{array}{c}0.0069 \\
(0.0054)\end{array}$ & $\begin{array}{c}0.0022 \\
(0.0016)\end{array}$ & $\begin{array}{c}0.0023 \\
(0.0015)\end{array}$ & $\begin{array}{c}0.0025 \\
(0.0026)\end{array}$ \\
\hline Environment & & & & $\begin{array}{c}-0.0207 * * \\
(0.0105)\end{array}$ & $\begin{array}{l}-0.0153 \\
(0.0124)\end{array}$ & $\begin{array}{l}-0.0210 \\
(0.0160)\end{array}$ & $\begin{array}{l}-0.0219 \\
(0.0160)\end{array}$ & $\begin{array}{l}-0.0220^{*} \\
(0.0118)\end{array}$ \\
\hline Housing & & & & $\begin{array}{l}0.0073^{*} \\
(0.0041)\end{array}$ & $\begin{array}{l}0.0068 * \\
(0.0040)\end{array}$ & $\begin{array}{c}0.0070 * * \\
(0.0026)\end{array}$ & $\begin{array}{c}0.0067 * * \\
(0.0026)\end{array}$ & $\begin{array}{c}0.0064 \\
(0.0044)\end{array}$ \\
\hline Health & & & & $\begin{array}{l}-0.0157 \\
(0.0408)\end{array}$ & $\begin{array}{l}-0.0278 \\
(0.0435)\end{array}$ & $\begin{array}{l}-0.0176 \\
(0.0379)\end{array}$ & $\begin{array}{l}-0.0232 \\
(0.0364)\end{array}$ & $\begin{array}{l}-0.0042 \\
(0.0343)\end{array}$ \\
\hline Recreation & & & & $\begin{array}{l}-0.0084 \\
(0.0196)\end{array}$ & $\begin{array}{l}-0.0081 \\
(0.0194)\end{array}$ & $\begin{array}{l}-0.0087 \\
(0.0120)\end{array}$ & $\begin{array}{l}-0.0081 \\
(0.0125)\end{array}$ & $\begin{array}{c}-0.0097 \\
(0.0179)\end{array}$ \\
\hline Education & & & & $\begin{array}{l}-0.0130 \\
(0.0431)\end{array}$ & $\begin{array}{l}-0.0181 \\
(0.0462)\end{array}$ & $\begin{array}{l}-0.0130 \\
(0.0293)\end{array}$ & $\begin{array}{l}-0.0092 \\
(0.0285)\end{array}$ & $\begin{array}{l}-0.0234 \\
(0.0418)\end{array}$ \\
\hline SocialProtect & & & & $\begin{array}{c}-0.0951 * * \\
(0.0433)\end{array}$ & $\begin{array}{c}-0.0970 * * \\
(0.0401)\end{array}$ & $\begin{array}{c}-0.0957 * * \\
(0.0386)\end{array}$ & $\begin{array}{c}-0.1016 * * * \\
(0.0358)\end{array}$ & $\begin{array}{c}-0.0831 * * \\
(0.0423)\end{array}$ \\
\hline \#Observations & 299 & 299 & 279 & 279 & 277 & 279 & 279 & 272 \\
\hline $\begin{array}{l}\text { \#Countries } \\
\mathrm{R}^{2} \\
\text { F-test }\end{array}$ & 15 & 15 & 15 & 15 & 15 & $\begin{array}{c}15 \\
0.2395 \\
1.54[0.099]\end{array}$ & $\begin{array}{c}15 \\
0.2377\end{array}$ & $\begin{array}{c}15 \\
0.1908 \\
1.54[0.097]\end{array}$ \\
\hline $\begin{array}{l}\text { LM-test } \\
\text { Hausman-test }\end{array}$ & & & & & & & $\begin{array}{c}0.02[0.887] \\
24.12[0.087]\end{array}$ & \\
\hline Endog.-test & & & & & & & & $71.20[0.000]$ \\
\hline
\end{tabular}

Notes: See Table 1. All variables in growth rates (except Schooling and OutputGap); in regression 5, the expenditure components are in growth rates of their per capita values. 
Table 6. Effects on income inequality: PIIGS versus the other countries

\begin{tabular}{|c|c|c|c|c|c|c|c|c|}
\hline & & PII & & & & Other c & untries & \\
\hline & (1) & $(2)$ & (3) & (4) & (1) & (2) & (3) & (4) \\
\hline L.Gini & $\begin{array}{c}0.3622 * * * \\
(0.1016)\end{array}$ & $\begin{array}{c}0.3470 * * * \\
(0.0992)\end{array}$ & $\begin{array}{c}0.3758 * * * \\
(0.1320)\end{array}$ & $\begin{array}{c}0.3256^{* * *} \\
(0.1422)\end{array}$ & $\begin{array}{c}0.3390 * * * \\
(0.0566)\end{array}$ & $\begin{array}{c}0.3391 * * * \\
(0.0560)\end{array}$ & $\begin{array}{c}0.3039 * * * \\
(0.0734)\end{array}$ & $\begin{array}{c}0.3024 * * * \\
(0.0803)\end{array}$ \\
\hline RealGDPpc & $\begin{array}{c}-0.4304 * * * \\
(0.1008)\end{array}$ & $\begin{array}{c}-0.4258 * * * \\
(0.1005)\end{array}$ & $\begin{array}{c}-0.4089 * * * \\
(0.1071)\end{array}$ & $\begin{array}{c}-0.2879 * * \\
(0.1221)\end{array}$ & $\begin{array}{c}-0.2527 * * * \\
(0.0706)\end{array}$ & $\begin{array}{c}-0.2529 * * * \\
(0.0701)\end{array}$ & $\begin{array}{c}-0.2783 * * * \\
(0.0836)\end{array}$ & $\begin{array}{c}-0.2191 * * \\
(0.0961)\end{array}$ \\
\hline Schooling & $\begin{array}{l}-0.2536 \\
(1.0475)\end{array}$ & $\begin{array}{l}-0.4551 \\
(1.0405)\end{array}$ & $\begin{array}{c}0.5484 \\
(1.5819)\end{array}$ & $\begin{array}{c}0.7290 \\
(1.6577)\end{array}$ & $\begin{array}{l}-0.2232 \\
(0.4222)\end{array}$ & $\begin{array}{l}-0.2129 \\
(0.4191)\end{array}$ & $\begin{array}{l}-0.1771 \\
(0.4921)\end{array}$ & $\begin{array}{c}0.0225 \\
(0.5177)\end{array}$ \\
\hline Openness & $\begin{array}{l}-0.0008 \\
(0.0372)\end{array}$ & $\begin{array}{l}-0.0007 \\
(0.0370)\end{array}$ & $\begin{array}{c}0.0114 \\
(0.0368)\end{array}$ & $\begin{array}{c}0.0033 \\
(0.0666)\end{array}$ & $\begin{array}{l}0.0481 * \\
(0.0256)\end{array}$ & $\begin{array}{l}0.0480 * \\
(0.0264)\end{array}$ & $\begin{array}{c}0.0746^{* *} \\
(0.0316)\end{array}$ & $\begin{array}{l}0.0579 * \\
(0.0350)\end{array}$ \\
\hline Wages & $\begin{array}{l}0.2207^{*} \\
(0.1141)\end{array}$ & $\begin{array}{l}0.2117^{*} \\
(0.1148)\end{array}$ & $\begin{array}{c}0.1303 \\
(0.1272)\end{array}$ & $\begin{array}{c}0.1791 \\
(0.1390)\end{array}$ & $\begin{array}{l}-0.0069 \\
(0.0837)\end{array}$ & $\begin{array}{l}-0.0042 \\
(0.0833)\end{array}$ & $\begin{array}{c}0.0707 \\
(0.0938)\end{array}$ & $\begin{array}{c}0.1170 \\
(0.1026)\end{array}$ \\
\hline Trend & $\begin{array}{l}-0.1170 \\
(0.1286)\end{array}$ & $\begin{array}{l}-0.0974 \\
(0.1275)\end{array}$ & $\begin{array}{l}-0.1825 \\
(0.1604)\end{array}$ & $\begin{array}{l}-0.2124 \\
(0.1735)\end{array}$ & $\begin{array}{l}-0.0271 \\
(0.0482)\end{array}$ & $\begin{array}{l}-0.0284 \\
(0.0479)\end{array}$ & $\begin{array}{l}-0.0190 \\
(0.0519)\end{array}$ & $\begin{array}{l}-0.0327 \\
(0.0546)\end{array}$ \\
\hline Consolidation & $\begin{array}{c}0.5202 \\
(0.8593)\end{array}$ & & & & $\begin{array}{c}0.0264 \\
(0.2758)\end{array}$ & & & \\
\hline SpendConsol & & $\begin{array}{c}0.9009 \\
(0.8941)\end{array}$ & & & & $\begin{array}{c}0.0149 \\
(0.3529)\end{array}$ & & \\
\hline TaxConsol & & $\begin{array}{c}0.3835 \\
(1.2204)\end{array}$ & & & & $\begin{array}{c}0.1528 \\
(0.3953)\end{array}$ & & \\
\hline TotalSpending & & & $\begin{array}{l}-0.0766^{*} \\
(0.0452)\end{array}$ & & & & $\begin{array}{c}0.0109 \\
(0.0309)\end{array}$ & \\
\hline PublicServices & & & & $\begin{array}{c}0.0388 \\
(0.0520)\end{array}$ & & & & $\begin{array}{c}0.0116 \\
(0.0322)\end{array}$ \\
\hline Defence & & & & $\begin{array}{l}-0.0157 \\
(0.0350)\end{array}$ & & & & $\begin{array}{l}-0.0099 \\
(0.0146)\end{array}$ \\
\hline PublicOrder & & & & $\begin{array}{c}0.0463 \\
(0.0682)\end{array}$ & & & & $\begin{array}{l}-0.0468 \\
(0.0391)\end{array}$ \\
\hline EconAffairs & & & & $\begin{array}{c}0.0041 \\
(0.0089)\end{array}$ & & & & $\begin{array}{c}0.0016 \\
(0.0028)\end{array}$ \\
\hline Environment & & & & $\begin{array}{l}-0.0469 \\
(0.0385)\end{array}$ & & & & $\begin{array}{l}-0.0128 \\
(0.0118)\end{array}$ \\
\hline Housing & & & & $\begin{array}{c}0.0077 \\
(0.0061)\end{array}$ & & & & $\begin{array}{c}0.0020 \\
(0.0068)\end{array}$ \\
\hline Health & & & & $\begin{array}{l}-0.0463 \\
(0.1015)\end{array}$ & & & & $\begin{array}{l}-0.0099 \\
(0.0379)\end{array}$ \\
\hline Recreation & & & & $\begin{array}{c}0.0006 \\
(0.0252)\end{array}$ & & & & $\begin{array}{l}-0.0026 \\
(0.0261)\end{array}$ \\
\hline Education & & & & $\begin{array}{l}-0.0304 \\
(0.0782)\end{array}$ & & & & $\begin{array}{l}-0.0120 \\
(0.0627)\end{array}$ \\
\hline SocialProtect & & & & $\begin{array}{c}-0.1378 * * \\
(0.0668)\end{array}$ & & & & $\begin{array}{l}-0.0802 * \\
(0.0445)\end{array}$ \\
\hline \#Observations & 90 & 90 & 86 & 86 & 209 & 209 & 193 & 193 \\
\hline \#Countries & 5 & 5 & 5 & 5 & 10 & 10 & 10 & 10 \\
\hline
\end{tabular}

Notes: See Table 5. Estimates obtained using the LSDVC estimator; 50 repetitions of the procedure are run to bootstrap the estimated standard errors, reported in parentheses; significance level at which the null hypothesis is rejected: ***, 1\%; **, 5\%; and $*, 10 \%$. All variables are in growth rates (except Schooling and OutputGap). 


\section{ANNEX}

Table A.1. Descriptive Statistics

\begin{tabular}{|c|c|c|c|c|c|}
\hline Variable & Obs. & Mean & Std. Dev. & Min. & Max. \\
\hline RealGDP & 345 & 2.09 & 2.78 & -8.54 & 11.27 \\
\hline Unemp & 330 & 3.55 & 18.37 & -26.91 & 112.54 \\
\hline Gini & 330 & 0.61 & 2.48 & -5.93 & 13.31 \\
\hline LabourForce & 330 & 0.22 & 1.46 & -16.61 & 4.13 \\
\hline PrivInvestment & 330 & -1.06 & 6.64 & -24.69 & 18.47 \\
\hline Schooling & 345 & 9.60 & 1.36 & 6.04 & 12.24 \\
\hline Openness & 330 & 2.10 & 6.03 & -20.67 & 15.56 \\
\hline Interest & 322 & -4.44 & 16.60 & -48.58 & 89.74 \\
\hline Wage & 314 & 1.03 & 1.98 & -8.53 & 8.51 \\
\hline RealGDPpc & 330 & 1.43 & 2.69 & -9.10 & 9.19 \\
\hline OutputGap & 345 & -0.25 & 2.85 & -8.17 & 10.65 \\
\hline Consolidation & 345 & 0.35 & 0.48 & 0.00 & 1.00 \\
\hline SpendConsol & 345 & 0.21 & 0.41 & 0.00 & 1.00 \\
\hline TaxConsol & 345 & 0.12 & 0.33 & 0.00 & 1.00 \\
\hline TotalSpending & 304 & 1.93 & 5.47 & -26.93 & 34.65 \\
\hline PublicServices & 304 & 0.75 & 6.34 & -20.38 & 29.34 \\
\hline Defence & 304 & 0.00 & 10.92 & -70.08 & 78.87 \\
\hline PublicOrder & 304 & 18.31 & 272.29 & -28.44 & 474.84 \\
\hline EconAffairs & 304 & 0.77 & 49.52 & -68.11 & 279.14 \\
\hline Environment & 304 & 3.88 & 17.29 & -73.08 & 210.17 \\
\hline Housing & 304 & 2.12 & 29.85 & -93.37 & 397.46 \\
\hline Health & 304 & 4.28 & 19.39 & -17.68 & 321.67 \\
\hline Recreation & 304 & 3.67 & 16.32 & -36.22 & 235.36 \\
\hline Education & 304 & 2.11 & 6.09 & -19.06 & 45.76 \\
\hline SocialProtect & 304 & 2.57 & 4.77 & -14.45 & 21.27 \\
\hline
\end{tabular}

Notes: All variables in growth rates (except Schooling, OutputGap and the consolidation dummies). Time period: 1990-2012 (annual data); Countries and respective years of fiscal consolidations: Austria (1996-1997, 2001-2002, 2011-2012), Belgium (1990, 1992-1994, 1996-1997, 2010-2012), Denmark (1995, 2011-2012), Finland (1992-1997, 2010-2012), France (1991, 195-1997, 1999-2000, 2011-2012), Germany (1991-1995, 1997-2000, 2003-2004, 2006-2007, 2011-2012), Greece (1991-1992, 1994-2000, 2010-2012), Ireland (2009-2012), Italy (1991-1998, 2004-2007, 2011-2012), Luxembourg (1996-1997), Netherlands (1991-1993, 2004-2005, 2011-2012), Portugal (2000, 2002, 2005-2007, 2010-2012), Spain (1992-1997, 2010-2012), Sweden (1993-1998), United Kingdom (1994-1999, 2010-2012).

Sources: OECD (2011), Restoring Public Finances; OECD (2015), Government at a Glance; Eurostat database (http://ec.europa.eu/eurostat/data/database); World Development Indicators (WDI); Standardized World Income Inequality Database (SWIID); Devries et al. (2011); Dellepiane and Hardiman (2012); Kataryniuk and Vallés (2015). 